\title{
Precambrian Geologic Evolution of the Teton RANGE, WESTERN WYOMING
}

\author{
KEVIN R. CHAMBERLAIN $\downarrow$ B. RON Frost $\downarrow$ CAROL D. Frost \\ DEPARTMENT OF GEOLOGY AND GEOPHYSICS \\ UNIVERSITY OF WYOMING $\downarrow$ LARAMIE
}

\section{$\downarrow \quad$ PROJECT SUMMARY}

The crystalline rocks that form the core of the Teton Range are part of the Wyoming Province, which is one of the oldest portions of North America. Study of the basement of the Tetons, coupled with the results of ongoing research in similar aged rocks exposed elsewhere in Wyoming, will provide information on how the crust evolved in the early Earth in general and in the Wyoming province in particular. In 1998 the project involved one week of fieldwork in Teton National Park to collect samples of key units for geochemical studies. This field work involved four faculty members from UW and a graduate student, who is doing the study as part of her MS thesis. The field work has been followed by several months of laboratory analysis at UW. We have characterized the rocks through thin section, stained slabs, and whole rock geochemical and $\mathrm{Nd}$, $\mathrm{Sr}$, and $\mathrm{Pb}$ isotopic methods. Geochronology is in progress: datable minerals have been isolated from samples of four different units and precise ages with uncertainties on the order of \pm 5 million years are forthcoming

\section{$\downarrow \quad$ SUMMARY OF FIELD WORK \\ During the field work we used available geologic maps from the US Geologic Survey to locate key areas for study (Love et al., 1992). We}

collected samples from the prominent dike that cuts the east face of Mount Moran. Dikes such as this record major crustal extension events and we hope to determine the age of this dike to constrain the timing of this Proterozoic extension. We collected samples from 2.54 billion year old (Ga.) Mt. Owen granodiorite, which is the youngest Archean rock in the range. This pluton has been well dated by the USGS (Zartman and Reed, 1998), but the isotope geochemistry of this pluton has not been characterized until now. We also sampled the Rendezvous Peak metagabbro, which occupies the southern portion of this range. This rock is largely undeformed and contacts with other units are not exposed. We hope to use geochronology to constrain its place in the history of the range.

We also collected samples from the older units in the range, including the Webb Canyon gneiss, the augen gneiss and the layered gneiss. We hope to use the $\mathrm{Nd}$ and $\mathrm{Sr}$ isotope compositions of these rocks to constrain their origins and to get precise U-Pb zircon ages from the Webb Canyon and augen gneisses to give us a better picture of the geologic history or the range.

\footnotetext{
$\uparrow \quad$ RESULTS

Geochemistry - Rocks are relatively potassic and lack the tonalites common to most
} 
Archean terranes. This is typical of other areas in the Wyoming Province, particularly of the Bighorns and the Wind Rivers. Rare Earth Elements (REEs). Four samples from the Mount Owen batholith have erns REE-enriched and have a strong negative Eu anomaly (Fig. 1). This is typical of granitic rocks that have formed by partial melting that has left plagioclase in the residua. The Webb canyon has a similar pattern, but has higher total REE abundance. The augen gneiss is more strongly depleted in the heavy REEs than either the Mt. Owen or the Webb canyon granites. Such a pattern suggests the presence of garnet in the residua. In contrast to the granitic rocks, the Rendezvous metagabbro has low REEs with a flat pattern and small positive Eu anomaly. Such a pattern is typical of mafic rocks that crystallized with plagioclase accumulation.

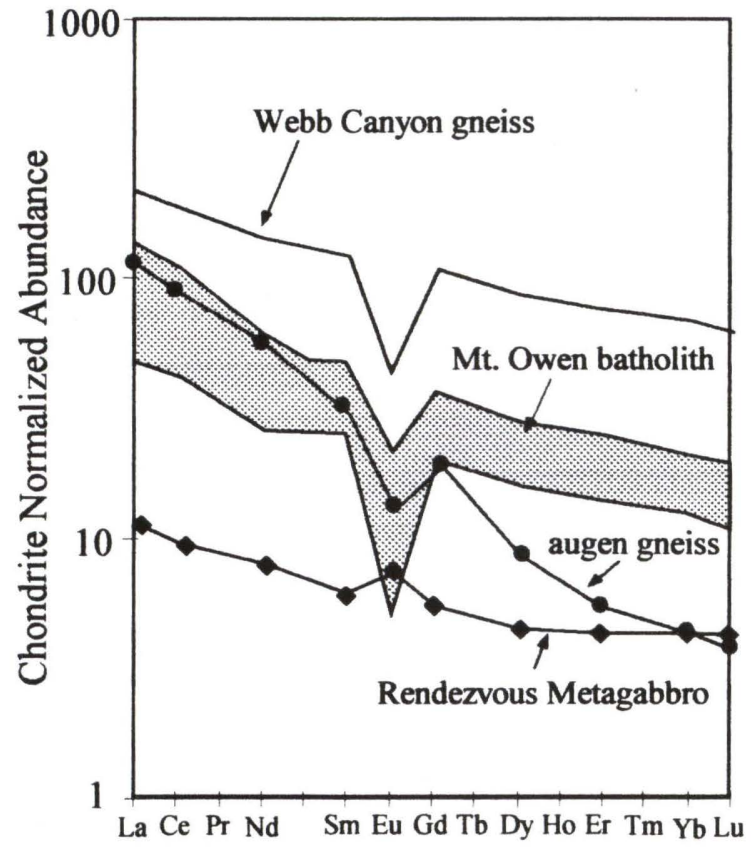

Figure 1. Chondrite-normalized Rare Earth pattern from Archean rocks in the Tetons.

Nd-Sr isotopes The rocks from the Tetons show a range of $\mathrm{Nd}$ isotope values, with $\square_{\mathrm{Nd}}$ ranging from +3 (which is nearly a mantle value at this time) to more than -7 , which would be more typical of crustal rocks (Fig. 2). This variation is best seen in the range in Nd model ages, a measure of the time at which the REEs in the rock were extracted from a mantle reservoir. The youngest rock, the Mt. Owen granite, has a low $\square_{\mathrm{Nd}}$ and $\mathrm{Nd}$ model age of $3.6 \mathrm{Ga}$, indicating that its source area contained significant amounts of old crust. The granite is peraluminous and both the old $\mathrm{Nd}$ model age and the rock composition are consistent with a source that included metasediments derived from the Archean crust of the Wyoming Province.

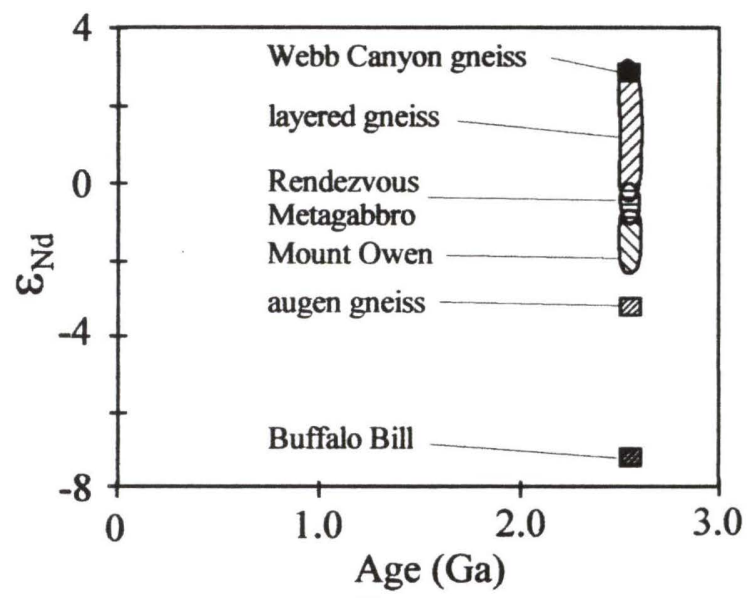

Figure 2: Variation of $\square_{\mathrm{Nd}}$ for rocks from the Tetons at $2.54 \mathrm{Ga}$, the age of the Mt. Owen granodiorite.

Many of the samples of the layered gneiss have high $\square_{\mathrm{Nd}}$ and relatively young Nd model ages, around $2.7 \mathrm{Ga}$. These rocks cannot be much younger than $2.68 \mathrm{Ga}$, because they are intruded by the ca. $2.68 \mathrm{Ga}$ Webb Canyon gneiss. This suggests that some of the rocks in the Tetons are of juvenile origin, in distinct contrast to gneisses in the Wind Rivers. Such "juvenile" rocks could represent island arcs or accretionary sediments.

The discovery of young $\mathrm{Nd}$ model ages is so important that we have obtained samples collected by Hildebrandt (1989) for additional analyses. These samples have been powdered and dissolved and isotopic analyses are presently underway.

Geochronology We have made significant progress toward dating samples of the Webb Canyon gneiss, the augen gneiss, the Rendezvous metagabbro, and the Mount Moran dike. Rocks have been crushed and the U-bearing minerals, zircon principally, have been separated through the use of magnetic and density techniques. The zircons are presently in the process of being dissolved and the analysis of the $\mathrm{U}$ and $\mathrm{Pb}$ isotopic compositions will be undertaken in the coming months. 


\section{SIGNIFICANCE}

Our initial work on the Tetons has shown the that the age of the last penetrative deformation in the Archean rocks of the Tetons is synchronous with the intrusion of the Webb Canyon gneiss, which has been interpreted to be younger than $2.7 \mathrm{Ga}$ (Zartman and Reed, 1998). This age is considerably younger than the last penetrative deformation in the Bighorn Mountains but is similar to the age of the last penetrative deformation in the Wind River Range (Frost et al., 1998), the Seminoe and Ferris Mountains (Bowers and Chamberlain, 1993), and the northern Laramie Range. This suggests that in the time period of ca. 2.6-2.7 $\mathrm{Ga}$ a mobile belt extended across the southern margin of the Wyoming province. Although the basement in the Tetons appears to share a similar deformation age to those in the Wind Rivers, the isotopic compositions of the gneisses from the Tetons are distinctly different from those in the Wind River Range. The Tetons contain rocks that have had a much shorter crustal history than similar-looking gneisses in the Wind Rivers. It is possible that layered gneisses with the young $\mathrm{Nd}$ model ages in the Tetons are part of an accreted terrane. If so, this is the first evidence that exotic terranes were accreted to the margin of the Wyoming Craton in the Archean.

\section{$\uparrow \quad$ Future Plans}

The results from our Teton studies have already had a major impact on our understanding of the evolution of the Wyoming province. It has allowed us to put together a model suggesting that the southern portion of the Wyoming province was a mobile belt during the period of 2.6 to 2.8 billion years ago. Much of this mobile belt was developed on the old margin of the Wyoming province, but it is possible that some of the Tetons represent an accreted terrane. We plan to submit a proposal to NSF this coming June to continue our study of the Wyoming Province to test this model. This proposal seeks to study the Precambrian outcrops in the Tetons, Wind River Range, Seminoe-Ferris Mountains, and northern Laramie Range to see if we can constrain the age of this mobile belt. If this proposal is funded we plan significant further work in the Tetons to see if we can map the limits of the possible accreted terrane.

\section{Literature Cited}

Bowers, N.E., and Chamberlain, K.R. 1993. New structural and geochronological constraints on an Archean shear zone in the central Wyoming Province, Ferris Mountains, Carbon County, Wyoming: GSA Abstracts with Programs. 25:A47.

Frost, C.D., Frost, B.R., Chamberlain, K.R., and Hulsebosch, T.P. 1998. The Late Archean history of the Wyoming Province as recorded by granitic magmatism in the Wind River Range, Wyoming. Precambrian Research 89:145-173.

Hildebrandt, P.K.. $1989 . \quad$ Petrology, thermobarometry and geochemistry of the Archean layered gneiss, Teton Range, Wyoming. Unpub Master's thesis, Colorado State University. Fort Collins, CO, United States.

Love, J.D., Reed, J.C., and Christiansen, A.C., 1992, Geologic map of Grand Teton National Park, Teton County, Wyoming. U.S. Geological Survey Misc. Investigation Series, Map I-2031

Zartman, R.E. and J.C. Reed. 1998. Zircon geochronology of the Webb Canyon Gneiss and the Mount Owen quartz monzonite, Teton Range, Wyoming: Significance to dating Late Archean Metamorphism in the Wyoming Craton. The Mountain Geologist. v 35, no. 2. 71-77. 